\title{
PRESTASI KERJA PEGAWAI DAN KINERJA BADAN KEPEGAWAIAN PENDIDIKAN DAN PELATIHAN ACEH
}

\author{
Mirnawati ${ }^{1}$, Amri $^{2}$, T. Roli Ilhamsyah Putra ${ }^{3}$ \\ 1) Magister Manajemen Program Pascasarjana Universitas Syiah Kuala Banda Aceh \\ ${ }^{2,3)}$ Fakultas Ekonomi Universitas Syiah Kuala
}

\begin{abstract}
The purpose of this study was to determine (1) the state of motivation, discipline, leadership style employee performance and organizational performance, (2) the influence of motivation, discipline and leadership style either simultaneously or partially on the performance of employees, (3) the influence of motivation, discipline and style leadership both simultaneously and partially on the performance of the organization and (4) the effect of employee performance to organizational performance and (5) the indirect effect of motivation, discipline and leadership style of the performance of the organization through employee performance Personnel Board Education And Training Aceh. This research was conducted at the Personnel Board Education And Training Aceh, whereas the object of this study was the influence of motivation, discipline, leadership style, employee performance and the performance of Civil Service Agency of Education and Training Aceh. These results indicate that employee motivation, discipline and leadership style and a significant positive effect on employee performance, then the results also showed that work motivation, discipline and leadership style positive and significant impact on job satisfaction Personnel Board Education And Training Aceh, while the performance of employees positive and significant impact on the performance of BKPP Aceh and there is indirect influence motivation, discipline and leadership style of the performance of the organization through employee performance Personnel Board Education And Training Aceh.
\end{abstract}

Keywords: Motivation, Discipline, Leadership Style, Employee Performance and Organizational Performance

\begin{abstract}
Abstrak: Tujuan penelitian ini adalah untuk mengetahui (1) keadaan motivasi, disiplin, gaya kepemimpinan kinerja pegawai dan kinerja organisasi, (2) pengaruh motivasi, disiplin dan gaya kepemimpinan baik secara simultan maupun parsial terhadap kinerja pegawai, (3) pengaruh motivasi, disiplin dan gaya kepemimpinan baik secara secara simultan maupun parsial terhadap kinerja organisasi dan (4) pengaruh kinerja pegawai terhadap kinerja organisasi dan (5) pengaruh tidak langsung motivasi, disiplin dan gaya kepemimpinan terhadap kinerja organisasi melalui kinerja pegawai Badan Kepegawaian Pendidikan Dan Pelatihan Aceh. Penelitian ini dilakukan pada Badan Kepegawaian Pendidikan Dan Pelatihan Aceh, sedangkan yang menjadi objek penelitian ini adalah pengaruh motivasi, disiplin, gaya kepemimpinan, kinerja pegawai dan kinerja Badan Kepegawaian Pendidikan dan Pelatihan Aceh. Hasil penelitian ini menunjukkan bahwa motivasi kerja, disiplin dan gaya kepemimpinan berpengaruh positif dan signifikan terhadap kinerja pegawai, kemudian hasil penelitian juga menunjukkan bahwa motivasi kerja, disiplin dan gaya kepemimpinan berpengaruh positif dan signifikan terhadap kepuasan kerja Badan Kepegawaian Pendidikan Dan Pelatihan Aceh, sedangkan kinerja pegawai berpengaruh positif dan signifikan terhadap kinerja BKPP Aceh dan terdapat pengaruh tidak langsung motivasi, disiplin dan gaya kepemimpinan terhadap kinerja organisasi melalui kinerja pegawai Badan Kepegawaian Pendidikan Dan Pelatihan Aceh.
\end{abstract}

Kata kunci: Motivasi, Disiplin, Gaya Kepemimpinan, Kinerja Pegawai dan Kinerja Organisasi

\section{PENDAHULUAN}

Kinerja pegawai merupakan pencapaian hasil dari tugas dan tanggungjawab yang telah dibebankan kepadanya. Badan Kepegawaian Pendidikan dan Pelatihan Provinsi Aceh
(BKPPA) merupakan salah satu organisasi yang bernaung pada Satuan Kerja Pemerintah Aceh (SKPA) yang mempunyai tugas dan fungsi dalam penyelenggaraan pendidikan dan pelatihan bagi aparatur pemerintah terutama

139 - Volume 4, No. 4, November 2015 
dalam peningkatan kinerja pegawai. Namun dalam kenyataannya menunjukkan bahwa kinerja aparatur pemerintah khususnya di BKPPA masih tergolong rendah, hal ini dapat dilihat dari banyak pekerjaan yang tidak selesai tepat waktu yang telah ditentukan dimana sebanyak $45 \%$ pegawai tidak dapat menyelesaikan pekerjaan tepat waktu, pegawai kurang tekun dalam menjalankan tugas dan tanggung jawabnya dimana sebanyak 35\% pegawai tidak dapat mencapai target kerja yang telah ditetapkan oleh pimpinan, kemudian rendahnya disiplin kerja pegawai dimana sebanyak 37\% pegawai masuk kantor tidak tepat waktu serta kurangnya penghargaan dari pimpinan terhadap pegawai yang berprestasi, sehingga mendorong pegawai lain kurang bersemangat dalam bekerja.

Disiplin kerja merupakan sikap yang sangat diperlukan dan mendapat perhatian dalam setiap pekerjaan yang dilakukan oleh setiap orang dalam usaha untuk meningkatkan kinerja guna mencapai tujuan organisasi. Menurut Singodimedjo, (2007) disiplin kerja adalah sikap kesediaan dan kerelaan seseorang untuk mematuhi dan mentaati norma-norma peraturan yang berlaku di sekitarnya.

Dalam rangka meningkatkan kualitas sumber daya manusia pada Badan Kepegawaian Pendidikan dan Pelatihan Provinsi Aceh telah bekerja sama dengan United Nations Development Programme Programme (UNDP) melalui Program Transformasi Pemerintahan Aceh, Aceh Goeverment Transformation Program (AGTP) untuk memperkuat kapasitas institusionalnya untuk kesuksesan masa transisi dan keberlanjutan proses pemulihan di Provinsi Aceh, dalam rangka meningkatkan kualitas sumber daya manusia pegawai pada Badan Kepegawaian Pendidikan dan Pelatihan Provinsi Aceh.

Setiap organisasi pasti memerlukan manajemen yang berkaitan dengan usaha-usaha untuk mencapai tujuan tertentu bagi kemajuan organisasi tersebut. Tidak hanya pada sektor swasta, sektor publik juga memerlukan manajemen yang baik agar dapat memberikan pelayanan kepada publik atau masyarakat yang memerlukan dengan baik pula. Berhasil atau tidaknya suatu organisasi dalam mencapai tujuannya tergantung oleh keberhasilannya dari pada individu organisasi itu sendiri dalam menjalankan tugas mereka.

Salah satu faktor yang dapat mempengaruhi peningkatan kinerja pegawai dan kinerja BKPPA adalah adanya motivasi kerja yang tinggi yang dimiliki oleh pegawai, Ermayanti (2001:3). Motivasi kerja yang rendah yang dimiliki oleh pegawai BKPPA saat ini menjadi salah satu faktor penghambat tercapainya tujuan secara individual dan tujuan secara organiasi. Hal ini dapat dilihat dari sikap pegawai yang cenderung malas untuk menyelesaikan pekerjaan yang telah menjadi tugasdan tanggung jawabnya masing-masing, kemudian banyak pegawai yang hanya datang tepat waktu untuk absen elektrik dan setelah absen banyak pegawai yang keluar kantor untuk keperluan yang masih kurang jelas, sehingga hal ini mengakibatkan terjadinya kinerja yang rendah.

Volume 4, No. 2, Mei $2015 \quad-140$ 
Fenomena yang terjadi pada BKPPA saat ini adalah masih rendahnya kinerja karyawan terutama dalam memberikan pelayanan kepada masyarakat. Di samping itu rendahnya kinerja pegawai juga dapat dilihat rencana kerja yang tidak matang, realisasi kerja yang tidak mencapai target, pegawai banyak yang tidak melaksanakan perintah atasan maupun target kerja yang rendah. Di mana secara umum tugas dan fungsi dari BKPPA adalah melaksanakan kegiatan teknis dan administrasi sesuai dengan ketentuan yang berlaku untuk mendukung kelancaran tugas pokok BKPPA. Rendahnya kinerja BKPPA yaitu tidak tercapai sesuai dengan target yang telah ditentukan, kurangnya koordinasi dalam pelaksanaan tugas antar bidang organisasi, masih kurangnya koordinasi dengan instansi lain, maupun tidak tepatnya waktu pelaporan hasil kegiatan kepada atasan sesuai dengan program yang telah dijalankan.

\section{KAJIAN KEPUSTAKAAN}

\section{Kinerja Organisasi}

Kinerja organisasi merupakan capaian kerja yang dihasilkan secara bersama-sama oleh seluruh komponen sumber daya dalam suatu organisasi sesuai dengan target yang telah ditetapkan. Dalam penelitian ini kinerja organisasi yang dimaksudkan adalah hasil atau pencapaian dari hasil kerja seluruh sumber daya manusia pada BKPPA dalam memberikan pelayanan kepada para pegawai dilingkungan Pemerintah Aceh.

Bila dikaji dari tujuan dan misi utama kehadiran organisasi publik adalah untuk memenuhi kebutuhan dan melindungi kepentingan publik, kelihatannya sederhana sekali ukuran kinerja organisasi publik, namun tidaklah demikian kenyataannya, karena hingga kini belum ditemukan kesepakatan tentang ukuran kinerja organisasi publik.

Berkaitan dengan kesulitan yang terjadi dalam pengukuran kinerja organisasi publik ini dikemukakan oleh Dwiyanto (2007: 1), "kesulitan dalam pengukuran kinerja organisasi pelayanan publik sebagian muncul karena tujuan dan misi organisasi publik seringkali bukan hanya kabur akan tetapi juga bersifat multidimensional. Organisasi publik memiliki stakeholders yang jauh lebih banyak dan kompleks ketimbang organisasi swasta. Stakeholders dari organisasi publik seringkali memiliki kepentingan yang berbenturan satu dengan yang lainnya, akibatnya ukuran kinerja organisasi publik dimata para stakeholders juga menjadi berbeda-beda".

\section{Kinerja Pegawai}

Kinerja pada dasarnya merupakan hasil kerja secara kualitas dan kuantitas yang dicapai seorang pegawai dalam melaksanakan tugasnya sesuai tanggung jawab yang diberikan, kinerja merupakan terjemahan dari "performance" yang berarti perbuatan, prestasi, pelaksanaan pekerjaan yang berdayaguna serta berhasilguna. Orang-orang banyak memikirkan cara yang benar dalam bekerja untuk menghasilkan sesuatu yang bermanfaat sesuai dengan harapan organisasi.

Dalam kamus Bahasa Indonesia (2005 : 503), pengertian kinerja diartikan sebagai

141 - Volume 4, No. 2, Mei 2015 
sesuatu yang harus dicapai, prestasi yang diperlihatkan dan kemauan kerja. Dalam pengertian lebih luas, kata performance selalu digunakan dengan kata-kata seperti job performance atau work performance yang berarti hasil kerja atau prestasi. Dari beberapa pendapat tentang pengertian kinerja sebagai prestasi dan kemampuan kerja, maka umumnya para ahli manajemen memberikan pengertian yang sama antara kinerja dengan prestasi kerja, atau juga dengan produktivitas kerja.

Menurut Dessler (2006 : 322) mengemukakan bahwa pada dasarnya kinerja lebih merupakan fungsi dari pelatihan, komunikasi, alat dan pengawasan serta motivasi pribadi. Tujuan dan standar kinerja harus sesuai dengan tujuan strategis organisasi/instansi.

Penilaian kerja dapat pula menjadi sumber kerisauan dan frustasi bagi manajer dan karyawan. Hal ini disebabkan ketidakpastian di sekitar sistem penilaian kinerja. Pada intinya penilaian kinerja dapat dianggap sebagai alat untuk menverifikasi bahwa individu-individu memenuhi standar kinerja yang telah ditetapkan serta membantu individu mengelola kinerja mereka. Faktor kritis yang berkaitan dengan keberhasilan jangka panjang organisasi adalah kemampuan untuk mengukur seberapa baik karyawannya bekerja serta menggunakan informasi tersebut guna memastikan pelaksanaannya memenuhi standar-standar sekarang dan terus meningkat sepanjang waktu. Teknik yang paling tua yang digunakan manajemen adalah melalui penilaian kerja (performance apprasial).

\section{Motivasi}

Menurut Hasibuan (2011: 92), motivasi berasal dari kata latin movere yang berarti dorongan atau daya penggerak. Motivasi diberikan kepada manusia, khususnya kepada para bawahan atau pengikut. Motivasi penting karena dengan motivasi ini diharapkan setiap individu karyawan mau bekerja keras dan antusias untuk mencapai produktivitas kerja yang tinggi. Motivasi adalah pemberian daya penggerak yang menciptakan kegairahan kerja seseorang agar mereka mau bekerja efektif dan terintegrasi dengan segala daya upayanya untuk mencapai kepuasan. Menurut Winardi (2010) motivasi adalah suatu kekuatan potensial yang ada dalam diri seorang manusia, yang dapat dikembangkannya sendiri atau dikembangkan oleh sejumlah kekuatan luar yang ada, intinya berkisar sekitar imbalan materi dan imbalan non materi, yang dapat mempengaruhi hasil kinerjanya secara positif atau secara negatif, dimana tergantung pada situasi dan kondisi yang dihadapi orang yang bersangkutan. Suatu dorongan jiwa yang membuat seseorang tergerak untuk melakukan tindakan yang produktif, baik yang berorientasi kerja untuk menghasilkan uang maupun yang tidak disebut motivasi kerja motivasi kerja yang dimiliki seorang pekerja berbeda-beda tentunya, dan juga berubah-ubah. Adapun menurut Manullang (2009: 176) mendefinisikan motivasi sebagai pekerjaan yang dilakukan oleh seorang manajer memberikan inspirasi, semangat, dan dorongan kepada orang lain. Dalam hal ini karyawan untuk mengambil tindakan-tindakan. 
Menurut pendapat Danim (2007: 2), motivasi adalah sikap dan nilai dasar yang dianut oleh seseorang atau sekelompok orang untuk bertindak atau tidak bertindak. Motivasi pada prinsipnya merupakan kemudi yang kuat dalam membawa seseorang melaksanakan kebijakan manajemen yang bisa terjelma dalam perilaku antusias, berorientasi pada tujuan, dan memiliki target kerja yang jelas, baik secara individual maupun kelompok.. Selanjutnya Handoko (2011: 252) memberikan pengertian motivasi sebagai berikut: "Motivasi adalah keadaan dalam pribadi seseorang yang mendorong keinginan individu untuk melakukan kegiatan-kegiatan tertentu guna mencapai tujuan.

Salah satu faktor penentu kinerja adalah motivasi. Menurut McClelland (dalam Handoko, 2011), Motivasi adalah proses pemberian motif (penggerak atau pendorong) kepada karyawan untuk dapat bekerja sedemikian rupa sehingga tujuan orang secara efisien dan efektif dapat tercapai. Masalah yang dibahas dan dipersoalkan dalam motivasi adalah bagaimana mendorong gairah kerja agar seseorang mau bekerja semaksimal mungkin dengan memberikan kemampuan dan keterampilan yang dimiliki untuk mencapai tujuan, sehingga peran motivasi ini sangat penting karena dengan motivasi diharapkan setiap karyawan mau bekerja keras sesuai dengan kompetensinya agar dapat mencapai produktivitas dan kinerja yang maksimal.
Disiplin

Disiplin berasal dari bahasa latin Discere yang berarti belajar. Dari kata ini timbul kata Disciplina yang berarti pengajaran atau pelatihan. Dan sekarang kata disiplin mengalami perkembangan makna dalam beberapa pengertian. Pertama, disiplin diartikan sebagai kepatuhan terhadap peraturan atau tunduk pada pengawasan, dan pengendalian. Kedua disiplin sebagai latihan yang bertujuan mengembangkan diri agar dapat berperilaku tertib. Menurut Terry (dalam Tohardi, 2002) dalam Edy Sutrisno bahwa Disiplin merupakan alat penggerak pegawai. Agar tiap pekerjaan dapat berjalan dengan lancar, maka harus diusahakan agar ada disiplin yang baik (Sutrisno, 2009:91). Disiplin kerja adalah suatu alat yang digunakan para pimpinan untuk berkomunikasi dengan karyawan agar mereka bersedia untuk mengubah suatu perilaku serta sebagai suatu upaya untuk meningkatkan kesadaran dan kesediaan seseorang mentaati semua peraturan organisasi dan norma-norma sosial yang berlaku (Veitzhal Rivai, 2011:824).

Selanjutnya menurut Singodimedjo (2012) dalam Edy Sutrino bahwa Disiplin adalah sikap kesediaan dan kerelaan seseorang untuk mematuhi dan mentaati norma-norma peraturan yang berlaku disekitarnya (Sutrisno, 2009:90). Dan menurut Heidjrachman dan Husnan (2002:15) mengungkapkan "Disiplin adalah setiap perseorangan dan juga kelompok yang menjamin adanya kepatuhan terhadap perintah" dan berinisiatif untuk melakukan

143 - Volume 4, No. 2, Mei 2015 
suatu tindakan yang diperlukan seandainya tidak ada perintah”. Kedisiplinan adalah fungsi operatif keenam dari Manajemen Sumber Daya manusia. Kedisiplinan ini merupakan fungsi operatif Manajemen Sumber Daya Manusia yang terpenting, karena semakin baik disiplin karyawan, semakin tinggi prestasi kerja yang dapat dicapainya.

\section{Gaya Kepemimpinan}

Di dalam mencapai tujuan organisasi, manajemen merupakan proses yang memiliki fungsi-fungsi tertentu, meliputi : perencanaan, pengorganisasian, pemotivasian, dan pengendalian. Secara tersendiri manajemen merupakan proses kerjasama dengan dan melalui orang-orang dan sekelompok untuk mencapai tujuan organisasi. Dari fungsi perencanaan dan pengorganisasian, kepemimpinan dalam pembahasan ini berada dalam fungsi pemotivasian.

Gaya kepemimpinan adalah corak kepemimpinan yang dibawakan oleh seorang pemimpin dalam mempengaruhi para pengikutnya. Gaya seorang pemimpin dalam menjalankan kepemimpinannya dipengaruhi oleh berbagai patern, Wursanti, (2013:200), antara lain : patern pendidikan, patern pengalaman, patern usia dan patern karakter (tabiat atau sifat yang ada pada diri pemimpin tersebut. Pengertian Gaya Kepemimpinan menurut Nawawi (2013:115) adalah :

"Gaya kepemimpinan merupakan perilaku atau cara yang dipilih atau digunakan pemimpin dalam mempengaruhi pikiran, perasaan,sikap dan perilaku para anggota organisasi atau bawahannya". Gaya tersebut dapat berbeda-beda atas dasar motivasi, kuasa ataupun orientasi terhadap tugas atau orang tertentu.

Menurut Heidjrachman dan Husnan (2012:224), Gaya kepemimpinan mewakili filsafat, ketrampilan, dan sikap pemimpin dalam politik. Gaya kepemimpinan adalah pola tingkah laku yang dirancang untuk mengintegrasikan tujuan organisasi dengan tujuan individu untuk mencapai tujuan tertentu.

Berdasarkan teori-teori sebelumnya, dapat disimpulkan bahwa gaya kepemimpinan adalah norma perilaku yang digunakan oleh seseorang pada saat orang tersebut mencoba mempengaruhi perilaku orang lain.

\section{METODE PENELITIAN}

\section{Lokasi dan Objek Penelitian}

Untuk mendapatkan data akurat dan dapat diuji kebenarannya serta keterangan yang mendukung penulisan karya akhir ini, maka penulis mengadakan penelitian yaitu pada Badan Kepegawaian Pendidikan dan Pelatihan Aceh, sedangkan yang menjadi objek penelitian ini adalah motivasi, disiplin, gaya kepemimpinan, kinerja pegawai dan kinerja Badan Kepegawaian Pendidikan dan Pelatihan Aceh.

\section{Populasi dan Sampel}

Populasi dalam penelitian ini adalah seluruh pegawai pada Badan Kepegawaian, Pendidikan dan Pelatihan (BKPP) Aceh yang berjumlah 194 orang. Sedangkan pengambilan 
sampel penelitian ini dilakukan dengan teknik Purposive Random Sampling terhadap semua pegawai, sedangkan yang menjadi responden sebanyak 155 orang.

\section{Peralatan Analisis Data}

Peralatan analisis data yang digunakan dalam penelitian ini adalah structural equation modelling (SEM) dengan bantuan program Amos 22. Model persamaan SEM adalah sekumpulan teknik-teknik statistikal yang memungkinkan pengujian sebuah rangkaian hubungan relatif rumit secara simultan (Ferdinand, 2006 : 181).

Tampilnya model yang rumit membawa dampak bahwa dalam kenyataannya proses pengambila keputusan manajemen adalah sebuah proses yang rumit atau merupakan sebuah proses yang multidimensional dengan berbagai pola hubungan kausalitas yang berjenjang. Oleh karenanya dibutuhkan sebuah model sekaligus alat analisis yang mampu mengakomodasi penelitian multidimensional itu.

SEM mampu memasukkan variabel laten kedalam analisis. Variabel laten adalah unobserved konsep yang diaproximasi dengan variabel terobservasi atau terukur yang diperoleh oleh responden lewat metode pengumpulan data (survey, test, observasi) dan sering disebut manifest variabel (Ghozali, 2014).

\section{HASIL PEMBAHASAN}

Pengaruh Motivasi Kerja terhadap Kinerja Pegawai BKPP Aceh

Parameter estimasi untuk pengujian pengaruh motivasi kerja terhadap kinerja pegawai menunjukkan nilai CR sebesar 4,393 dan dengan probabilitas sebesar 0,000. Kedua nilai yang diperoleh tersebut memenuhi syarat untuk penerimaan $\mathrm{H} 1$ yaitu nilai $\mathrm{CR}$ sebesar 4,393 yang lebih besar dari 1,97 dan probabilitas yang lebih kecil dari 0,05.

\section{Pengaruh Disiplin kerja Terhadap Kinerja pegawai BKPP Aceh}

Parameter estimasi untuk pengujian pengaruh disiplin kerja terhadap kinerja pegawai menunjukkan nilai $\mathrm{CR}$ sebesar 4,553 dan dengan probabilitas sebesar 0,000. Kedua nilai tersebut diperoleh memenuhi syarat untuk penerimaan $\mathrm{H} 2$ yaitu nilai $\mathrm{CR}$ sebesar 4,553 yang lebih besar dari 1,97 dan probabilitas yang lebih kecil dari 0,05.

\section{Pengaruh Gaya kepemimpinan Terhadap Kinerja pegawai BKPP Aceh}

Parameter estimasi untuk pengujian pengaruh gaya kepemimpinan terhadap kinerja pegawai menunjukkan nilai $\mathrm{CR}$ sebesar 3,316 dan dengan probabilitas sebesar 0,000. Kedua nilai yang diperoleh tersebut memenuhi syarat untuk penerimaan $\mathrm{H} 3$ yaitu nilai $\mathrm{CR}$ sebesar 3,316 yang lebih besar dari 1,97 dan probabilitas yang lebih kecil dari 0,05 . 


\section{Motivasi kerja Berpengaruh Positif dan Signifikan Terhadap Kinerja BKPP Aceh}

Parameter estimasi untuk pengujian pengaruh motivasi kerja terhadap kinerja organisasi menunjukkan nilai CR sebesar 5,353 dan dengan probabilitas sebesar 0,000. Kedua nilai tersebut diperoleh memenuhi syarat untuk penerimaan $\mathrm{H} 4$ yaitu nilai $\mathrm{CR}$ sebesar 5,353 yang lebih besar dari 1,97 dan probabilitas yang lebih kecil dari 0,05.

\section{Disiplin kerja Berpengaruh Positif dan Signifikan Terhadap Kinerja BKPP Aceh}

Parameter estimasi untuk pengujian pengaruh disiplin kerja terhadap kinerja organisasi menunjukkan nilai CR sebesar 4,907 dan dengan probabilitas sebesar 0,000 . Kedua nilai tersebut diperoleh memenuhi syarat untuk penerimaan H5 yaitu nilai CR sebesar 4,907 yang lebih besar dari 1,97 dan probabilitas yang lebih kecil dari 0,05.

\section{Gaya kepemimpinan Berpengaruh Positif dan Signifikan Terhadap Kinerja BKPP Aceh}

Parameter estimasi untuk pengujian pengaruh gaya kepemimpinan terhadap kinerja organisasi menunjukkan nilai CR sebesar 5,416 dan dengan probabilitas sebesar 0,000. Kedua nilai tersebut diperoleh memenuhi syarat untuk penerimaan H6 yaitu nilai CR sebesar 5,416 yang lebih besar dari 1,97 dan probabilitas yang lebih kecil dari 0,05.
Kinerja pegawai Berpengaruh Positif dan Signifikan Terhadap Kinerja BKPP Aceh

Parameter estimasi untuk pengujian pengaruh kinerja pegawai terhadap kinerja organisasi menunjukkan nilai CR sebesar 5,492 dan dengan probabilitas sebesar 0,000. Kedua nilai tersebut diperoleh memenuhi syarat untuk penerimaan $\mathrm{H} 7$ yaitu nilai CR sebesar 5,492 yang lebih besar dari 1,97 dan probabilitas yang lebih kecil dari 0,05.

\section{KESIMPULAN DAN SARAN}

\section{Kesimpulan}

1. Hasil uji deskriptif menunjukkan bahwa motivasi kerja, disiplin kerja, gaya kepemimpinan, kinerja pegawai dan kinerja organisasi BKPP Aceh sudah berjalan dengan baik, karena diperoleh nilai rerata lebih besar daripada nilai rerata harapan.

2. Hasil penelitian menunjukkan bahwa motivasi kerja berpengaruh positif dan signifikan terhadap kinerja pegawai BKPP Aceh.

3. Hasil penelitian juga membuktikan bahwa disiplin kerja berpengaruh positif dan signifikan terhadap kinerja pegawai BKPP Aceh.

4. Hasil penelitian in juga membuktikan bahwa gaya kepemimpinan berpengaruh positif dan signifikan terhadap kinerja pegawai BKPP Aceh.

5. Hasil penelitian lain juga membuktikan bahwa motivasi kerja berpengaruh positif dan signifikan terhadap kinerja BKPP Aceh. 
6. Disiplin kerja yang dirasakan oleh pegawai juga berpengaruh positif dan signifikan terhadap kinerja BKPP Aceh.

7. Hasil penelitian terhadap gaya kepemimpinan membuktikan bahwa gaya kepemimpinan berpengaruh positif dan signifikan terhadap kinerja BKPP Aceh.

8. Hasil penelitian juga membuktikan bahwa kinerja pegawai berpengaruh positif dan signifikan terhadap kinerja BKPP Aceh.

\section{Saran}

1. Dalam rangka meningkatkan kinerja pegawai pada BKPP Aceh berdasarkan variabel motivasi kerja, yang perlu diperhatikan adalah pimpinan selalu memberikan penghargaan kepada karena karena prestasi kerja yang telah diraihnya.

2. Disiplin kerja juga perlu mendapatkan perhatian, dimana indikator yang perlu diperhatikan adalah masalah sikap dan tingkah laku pegawai harus selalu menunjukkan pada sikap penuh tanggung jawab.

3. Mengenai gaya kepemimpinan pegawai juga harus menjadi perhatian dari pimpinan, terutama berkaitan dengan pimpinan harus selalu memberikan penghargaan, apabila tugas dapat dilaksanakan sesuai dengan rencana.

4. Untuk meningkatkan kinerja pegawai secara keseluruhan, maka faktor yang perlu mendapatkan perhatian adalah meningkatkan kualitas pekerjaan yang dilakukan agar selalu mendekati sempurna atau memenuhi tujuan yang diharapkan dari pekerjaan tersebut.

5. Dalam rangka meningkatkan kinerja organisasi, yang perlu mendapatkan perhatian adalah kantor harus berusaha memberikan pelayanan berkualitas kepada masyarakat, melakukan kegiatan yang ditujukan untuk kepentingan masyarakat serta melakukan proses operasi selalu dilakukan oleh pimpinan dalam rangka pengawasan kerja yang lebih baik.

\section{DAFTAR KEPUSTAKAAN}

Dessler, G. 2006. Manajemen Sumber Daya Manusia. Jilid 1.Edisi 7. PT. Prenhallindo. Jakarta.

Dessler, G. 2004. Human Resource Management. 9th edition. Prentice Hall, New Jersey.

Elzi, S. H., dan Muhammad, Faisal, R. 2007. Pengaruh gaya kepemimpinan terhadap motivasi kerja.

Hasibuan, M. S. P. 2011. Manajemen Sumber Daya Manusia. Edisi Revisi. PT. Bumi Aksara. Jakarta.

Handoko, H. T. 2011. Manajemen Personalia dan Sumber Daya Manusia. Edisi kedua. Yogyakarta. BPFE Universitas Gadjah Mada

Istijanto. 2006. Riset Sumber Daya Manusia Cara Praktis Mendeteksi Dimensi-dimensi Kerja Karyawan. Jakarta: PT. Gramedia Pustaka Utama.

Keith, Davis, Jhon W. Newstrom. 1995. Perilaku Dalam Organisasi, Edisi Ketujuh, Erlangga,Jakarta.

Lleras, C. 2011. Path Analysis Pennsylvania State University University Park Pennsylvania USA

Mangkuprawira, S. 2003. Manajemen Sumber Daya Manusia Strategik. Edisi 2. Ghalia Indonesia. Jakarta.

Manullang, M. 2009. Manajemen Personalia. Edisi 3. Gadjah Mada University Press. Yogyakarta.

Moch. A. 1995. Psikologi Industri. Jakarta. Liberty.

Ruky, A. S. 2006. Sistem Manajemen Kinerja. Jakarta: PT. Gramedia Pustaka Utama.

Robbin. 2003. Alih Bahasa Yusuf Udaya, Teori Organisasi \& Struktur Organisasi. Jakarta.

147 - Volume 4, No. 2, Mei 2015 
Jurnal Manajemen

Pascasarjana Universitas Syiah Kuala

Robbins, Stephans. 1996. Organization Bahaviour, Seventh Edition, A Simon \& Schuster Company, Englewood Cliffs, New Jersey 07632.

Reksohadiprodjo, Sukanto dan Handoko H.T. 2011. Organisasi Perusahaan : Teori Struktur dan Perilaku. Edisi kedua. Yogyakarta : BPFE Universitas Gajah Mada.

Robbins, Stephans. 1994. Organization Theory, Structure, Design and Application, Alih Bahasa Yusuf Udara, Arean, Jakarta.

Safaria, Triantoro. 2004. Kepemimpinan Edisi Pertama. Graha Ilmu. Yogyakarta.

Stoner, J. A. F dan R. E. Freeman. 1994. Manajemen. Jilid 1. Edisi Kelima. Intermedia. Jakarta.

Suprihanto. 2006. Prestasi Kerja. www.google.com. [12 Januari 2009].

Simamora, Henry. 2006. Manajemen Sumber Daya Manusia. Cetakan pertama. Yogyakarta : YKPN.

Siagian, S. P. 1995. Teori Motivasi dan Aplikasinya, Jakarta : Rineka Cipta.

Sarwono, J. 2010. Analisis Jalur Untuk Riset Bisnis dengan SPSS. Edisi 5. Yogyakarta: Penerbit Andi.

Sitepu, N. S. K. 1994. Analisis Jalur. Bandung: Jurusan Statistik, FMIPA Univeristas Padjadjaran.

Susilo, M. 1992. Manajemen Sumber Daya Manusia. Jakarta : BPFE.

Wahjosumidjo. 1994. Kepemimpinan dan Motivasi. Ghalia Grafindo. Jakarta.

Winardi, J. 2010. Motivasi dan Pemotivasian dalam Manajemen. PT. Raja Grafindo Persada. Jakarta.

Wursanti, I. 2013. Dasar-Dasar Ilmi Organisasi. Yogyakarta : PT. Andi Offset.

Yukl, G. 2005. Kepemimpinan dalam Organisasi. Edisi Kelima. PT. Indeks, Jakarta. 